\title{
The Iron Cage of the Profession: A Critique on Closure in the Australian Accounting Profession
}

\author{
Gregory Kenneth Laing \\ Faculty of Business, University of the Sunshine Coast \\ Maroochydore, Australia \\ E-mail: glaing@usc.edu.au \\ Ronald William Perrin \\ School of Accounting \& Finance, Faculty of Commerce \\ University of Wollongong, Australia \\ E-mail: r.perrin@uow.edu.au
}

Received: December 22, $2010 \quad$ Accepted: January 24, $2011 \quad$ doi:10.5539/ass.v7n6p35

\begin{abstract}
This paper seeks to contribute to the literature on the process of closure that occurs within the constructs of professions. The discussion in this paper focuses on the professional accounting bodies in Australia and how they have devolved a form of bureaucratic control over the education process through the credentialing of membership and accreditation of accounting degrees. Weber's theory of bureaucracy in conjunction with Closure theory provide the framework upon which this critique is drawn. Implicit in the regulatory role of the accounting bodies is the justification of the practice of accounting and the status of the members of the professional bodies. Once those within the professional associations accept the right of the professional bodies to determine the educational requirements for membership along with the practice of accreditation of curriculum forms the iron cage. The practice of accreditation and credentialing exists in other disciplines such as medicine, engineering and law so that there exists parallels for claiming a legitimate basis for the intervention of the professional accounting bodies.
\end{abstract}

Keywords: Closure theory, Bureaucracy, Iron cage, Professions

\section{Introduction}

Various occupations have engaged in attempts to establish a professional identity. The tendency for occupations to seek the status of a profession has occurred over time and continues through to modern society. In the Middle Ages the status of a profession was sought and gained by the law, the clergy, medicine and university academics. In the more recent history dentistry, architecture and certain categories of engineers (e.g. civil engineers) had achieved professional status by the early part of the $20^{\text {th }}$ century. These were followed by psychology, nursing, accounting and several other scientific and engineering fields (Wilensky 1964). In the context of the accounting occupation there is a growing body of literature examining the early stages of establishing closure using the status of a profession (Lee 1990; Macdonald 1985), through to the more recent attempts in the United Kingdom (Walker \& Shakleton 1995, 1997; Robson, Willmott, Cooper \& Puxty 1994) and in a limited perspective of the Australian context (Chua \& Poullaos 1993). Whilst these studies primarily dealt with the various attempts at monopolizing the accounting occupation they also encompassed varying aspects of the professionalization process.

Research conducted by Wilensky (1964) identified the stages through which an occupation passes on its way to becoming a profession as being: (1) creation of a full time occupation; (2) establishment of a training school; (3) formation of a professional association; (4) formation of a code of ethics. Therefore, any occupation desirous of exercising professional authority will have to find a technical basis for its existence, assert an exclusive jurisdiction, link both skill and jurisdiction to standards of training and convince the public that the services are uniquely trustworthy (Wilensky 1964). Hall (1968) reported finding that the work done by the expert had to be informed by expert knowledge which in turn had to be guided by professional norms. Toren (1976) added that 
the number of members (size of the profession) and the length of time required for training, which is consider to relate to the level of professional qualification to meet professional status by a member, were important to the professionalization process. Professional occupations were characterized by Hall (1968) as being reflected by the attributes of: (1) a professional organization acting as a major reference point; (2) a belief that their work is a service to the public; (3) a belief in self regulation; (4) a sense of calling to the field; (5) autonomy in decision making. Research conducted by Snizek (1972) found these attributes were associated with the attitudes of members of a profession.

The purpose of this paper is to explore the accounting profession in Australia in the context of the dimensions of professionalism through the lens of closure theory. The focus of the analysis is on the establishment of jurisdiction over training and expert knowledge. This approach should provide further insights into the impact of the accounting profession on society in general and contextually the business environment in Australia. There are five accounting associations in Australia which represent their members interests. Three of these, the Institute of Chartered Accountants in Australia (ICAA), the Certified Practicing Accountants Australia (CPA), the National Institute of Accountants in Australia (NIA) are primarily concerned with financial accounting and auditing practices. The remaining two focus on managerial accounting and they are the Institute of Chartered Management Accountants (ICMA) and the Institute of Certified Management Accountants Australia (CMA).

\section{Closure Theory}

Weber used the term closure to explain the process of subordination whereby one group monopolises advantages by closing off opportunities to another group of outsiders which it considers inferior and therefore ineligible (Murphy 1986). Continuing the development of the Weberian theory of closure Parkin (1979) proposed that there are two reciprocal modes of closure, exclusion and usurpation. Exclusion involves the exercise of power through subordination to secure advantages by closing off the opportunities for group below it. Conversely, usurpation involves the exercise of power in an effort to gain the advantages reserved to a group above it. These concepts provide the means for interpreting the process by which a profession or professional organization mobilizes power in order to enhance or defend its share of resources or rewards (Parkin 1979; Murphy 1984). It is proposed that the professional accounting bodies in Australia fall within the definition of a bureaucracy, or in the case of Australia three separate bureaucracies which form the holy trinity of the accounting profession. Weber (1978) suggested that individuals tended to create bureaucracies to regulate social relationships and this certainly is evident in the accounting associations and the accounting profession.

\section{Dimensions of Professionalism}

In Australia, the ICAA, CPA and NIA have established organisational structures, consisting of national offices; divisional offices; and centres of excellence (at selected universities). The offices and centres of excellence are designed to attract senior people, that is people who are well known and respected in their field, and this serves to confirm the right of the bureaucracy to control and dictate the direction of the expert knowledge claimed by the profession. These structures administer regulatory control over the activities of members and exhibit the characteristics which Weber (1978) identified as relating to the pure or "ideal-type" bureaucracy, that is depersonalised; rationalistic; and rule-bound organisations. The way in which the ICAA, CPA and NIA have established constraints for entry into the accounting profession (in terms of membership) and control over the application of accounting practice (in terms of rules, regulations and accounting standards) is consistent with the findings of Wilenky (1964) and is a form of bureaucracy. The ICAA, CPA and NIA have established themselves as guardians of the profession through the credentialing of membership (exclusivity to the profession); special powers associated with accounting skills/practice; and the role they play in the creation of accounting theory which defines the area of expertise and their value to society.

Schumpeter (1951) suggested that professions may be viewed in terms of the monopoly they have over resources (such as knowledge and skills) which are relevant to the needs of society. This is evident in the accounting profession which has established a form of authority over the dissemination of knowledge (through education) and the practice of technical skills (through accreditation and certification of members) to meet the accounting requirements of the various associations. The Australian Federal government has also recognised the right of the ICAA, CPA and NIA to represent the accounting profession both in the provision of practical expertise (the Australian Tax Act and the Australian Corporations Act) by actually naming the associations in the relevant legislation as being the benchmark for recognition of accounting qualifications relevant to tertiary education. These acknowledgments by the government legislation serves to reinforce the authority and monopoly that these professional bodies hold over accounting in Australia.

The Institute of Chartered Accountants in Australia (ICAA), the Certified Practicing Accountants Australia (CPA) 
and the National Institute of Accountants are engaged in creating closure by exclusion with the appearance of a profession over which they hold a monopoly at least in Australia. There is a history in Australia of accounting associations attempting to assimilate or merge and when these attempts failed the recriminations against those which remained, "outside", was to minimize them as being "non-professional" or "para-professional" (West 1996). This type of activity is consistent with the process of professionalization which Feld (1964) described in terms of protective measures which define the boundaries between those in the profession and those outside. Interestingly the NIA were recipients of this treatment throughout the 1980's and 90's. However, since 2000 the NIA have followed the example of the CPA in an effort to gain recognition as a professional association. They introduced professional membership levels and established an educational program for their membership to aspire to - PNA (professional national accountant). In this regards the NIA have actively usurped the mantle of professionalism previously held by the other two bodies. To achieve this, the NIA hired academic authors to prepare submissions to government bodies on their behalf, and they actively canvassed political support for their inclusion in what had otherwise been the domain of the ICAA and CPA. That is representation on government committees and advisory boards pertaining to accounting regulation. The result has been that there are now three professional bodies representing the interest of accountants in Australia, at least in terms of the financial accounting realm of tax, auditing and financial accounting standards.

\subsection{Professional Monopoly of Education}

Monopoly of education is another important issue for the accounting profession, not only as a means of socialising and controlling the selection of prospective members, but also in terms of providing a tradition in training. After all, the profession is the guardian of the body of knowledge and this distinguishes and legitimates the profession from all others on the outside so who better to oversee and direct the educational process. As Jackson (1970) suggested all professions, through a process of socialisation, create a form of mass consciousness which resists any attempts to undermine the profession and the privileges that are enshrined in membership. Examples of this process are to be found in the history of medicine, law, engineering and psychology.

The more organised a profession is, the less its powers are likely to be challenged, and the more the profession will be identified for its monopolistic image by outsiders. In the accounting profession the image of the professional accountant is well established in society and the two bodies use advertising to reinforce the image, being careful not to discredit one-another in the process but to diminish the credibility of outsiders. For example, the CPA television and newspaper advertising campaign which used the slogans 'not your average accountant' and 'go places' to promote the idea that it's members possessed greater skills and knowledge in a demonstrable way, in contrast the ICAA advertising campaign which used the slogan ' number one in numbers'.

Through standardised and monopolised education, professional skills of accountants have acquired an appearance of measurement and comparison with respect to objective testing of competence in professional skills and length of time spent in acquiring such skills. In Australia the ICAA and CPA have insisted on an undergraduate Bachelor degree as the starting point for eligibility to membership, by contrast the NIA currently accept an Advanced level Diploma. These initial educational requirements can be completed in 2 to 3 years. Once a person has completed the tertiary education the next step is to complete the association membership program - coincidently all three associations now have almost identical modules and this new process is now scheduled over 2 years. Thus a person desirous of joining the professional ranks of either association can expect to take 4 to 5 years. There is also a practical experience requirement however this can be satisfied by work experience during the period of study. It is as if the skills themselves, rather than the individual, acquire a legitimate existence which may be expressed in terms of tangible and quantifiable competence. The profession has its role, in the education process, further strengthened as the arbitrator of objectively assessing (credentialing) the competence of its members. This monopoly over the education and credentialing is the structural condition which supports the notion of professional skills. Such control over credentialing results in a high exchange value in the competence it acknowledges and it also creates an artificial scarcity of professionals in the market place. Through the credentialing process socially produced knowledge is privately monopolised and artificially limited by the profession, impacting on the market value of professional services and justifying the price for the professional commodity.

Having the power to dictate the educational needs of the members of the profession does not mean that the best interests of the profession have always been served. Gynther $(1983,6)$ pointed out that the ICAA overlooked the development of relevant and new topics such as costing, management and business finance. As Gynther $(1983,7)$ observed in Australia and in the USA there tended to be times when the tail (referring to the profession) was waging the dog (referring to the providers of education). 


\subsection{Accreditation}

Accounting is a social construct, which exists because of society and the economic environment operating in that society. Examples that highlight this issue are to be found in the accounting systems which evolved in various communist societies. In these societies only information which conformed to government dictates was considered relevant and the accounting system ignored concepts such as efficient and effective use of resources. As a social construct, accountants as well as society at large need to be aware of the faults and fallibility of the theoretical assumptions underlying the body of knowledge favoured by the accounting profession.

The accounting profession exerts control over the practice of accounting by increasing the technical aspects, through codification and continuing to increase the rules and regulations applicable to the profession (Scheiwe, 1992). This monopolising of the discipline rationalises the nature and function of accounting further legitimating the profession and reducing possible intervention or evaluation from outside. It increases the amount of information to be disseminated through universities, as part of the teaching process. That is, the profession artificially increases the body of knowledge which increases the content for the curriculum.

Participation in the accreditation process legitimates the power of the profession and compromises the university, which adheres to the directions of the accreditation committee. The professional bodies establish limits on the pursuit of knowledge, by privileging one form of research and by attempting to objectify the requisite skills, all of which is an attempt to reassure their members that the activities of the profession are in their best interests as well as serving some common good for society. However, Becher (1994) warned that a profession faces the danger of becoming a group of self perpetuating experts who may abrogate to themselves the right to determine public good (in terms of education and membership to the profession).

\subsection{Teaching Implications}

The requirements of the profession dictate the technical skills and knowledge required to satisfy the entrance level requirements of the professional bodies. Attention is directed to content rather than the learning process. The university curriculum perpetuates the characteristics of the profession by accepting the defined body of knowledge which the profession has deemed acceptable. It should be noted that the professional bodies, or at least their members under the direction of such bodies, have created the body of knowledge which in turn is translated into curricular. The profession may depend upon societies' belief in the authority of universities to train or teach, however, the universities acquiesce to validate the content of their curriculum. Universities have become the providers of vocational training rather than centers for the creation and dissemination of knowledge.

Competencies of applicants are measured according to standards which are subjectively derived. The skills which are considered applicable are also subjectively derived from the experiences of those members of the profession who hold positions on the various committees within the professional bodies and see the potential graduates as a source or supply for their future needs. The curriculum tends to reflect the vocational aspects in that it emphasises techniques and rules promulgated by the professional bodies. There are few opportunities to broaden the concepts and theories beyond those which the profession consider relevant to the economic environment. Graduates are provided with the basic skills for thinking (logical analysis and problem solving) in accordance with the functional requirements of the profession, or at least the prescribed functions. However, there is a glimmer of hope with Coopers \& Lybrand, one of the largest accounting firms, reportedly (Rogerson, 1994, 1) coming out against the increasing trend toward standards which provide a "crutch for lazy minds". This raises the question of whether the university should provide a purely vocational training or a vocational orientated education which encourages intellectual development and preparation for life-long learning. Reliance on rote learning of accounting standards and basic principles would seem to overlook the possibility of producing graduates with potential to make a positive contribution to the profession and society in the future.

Accreditation is conducted on the basis of an annual review (by questionnaire) and a five yearly revision (by visit of joint committee). The requirements are set-out by both professional bodies in the "(1991). Guidelines for Joint Administration of Accreditation of Tertiary Institutions by the Professional Accounting Bodies". The areas covered are (1) staff; (2) students; (3) curriculum; (4) assessment \& results; (5) resources. The language of the joint accreditation documents (past and present) reflects the view that self regulators is in the best interests of society. However, this further strengthens the control of the professional associations and the iron cage by relegating the education aspect to that of a market driven formula enshrined in the language of curriculum and vocational standards. The NIA has yet to be accepted into the joint accreditation process, it remains on the periphery, a position which it has as yet to usurp. However, the NIA did write to all the universities in Australia in 2005 pointing out that they should be acknowledged as one of the professional accounting bodies that graduates could aspire to join upon completion of their respective accounting degrees. Interestingly, the universities almost universally acquiesced to this demand, only the most traditional or in the vernacular 'sandstone' universities have yet to comply. 


\subsection{Legal Recognition of the Accounting Profession}

The accounting profession has been given recognition in the Australian Corporations Act (2001) as amended and the Australian Income Tax Assessment Act (1936) as amended. Both of these acts make specific mention of the professional accounting bodies and require anyone acting as an accountant or auditor to be a member or to have the qualifications for entry to membership of the professional accounting bodies. The three professional accounting bodies are named in Section 9 of the Australian Corporations Act (2001) and in section 2AC of the Australian Securities and Investments Commission - Regulations. The Australian Corporations Act Regulations also recognizes the professional entry courses of the three accounting bodies (section 9.2.03) and identifies them using the term "Prescribed bodies" (section 9.2.04). Whilst this may have fallen short of the desired closure that the professional accounting bodies had sought, the legal recognition enhances and supports their position in society.

The Australian Corporations Act further strengthens the role of the professional accounting bodies by delegating the regulation of financial reporting requirements by adopting the Australian Accounting Standards. In doing so the legislation has released the control that it once had over the content and nature of financial reporting. To address any bureaucratic concerns that may arise from this abrogation of responsibility the legislation dictates the composition of the Australian Accounting Standards Board and allows for members other than representatives from the professional accounting bodies (Australian Corporations Act (2001) section 334(1). However, as Australia has adopted the International Accounting Standards the accounting profession continues to exert a greater degree of influence in determining the basis of the financial reporting process. In February 2010 the three accounting bodies made a joint submission to the Australian Federal Treasury (CPA, ICAA \& NIA 2010) commenting on proposed reforms to the reporting requirements under the Australian Corporations Act (2001). In the joint submission they state that they "represent over 180,000 professional accountants in Australia". This joint approach magnifies the relative power of the three accounting bodies in terms of their capacity to dominate the Australian accounting profession, which inevitably influenced the reforms considered by the Australian government.

\subsection{Historical Perspective}

An analysis of the historical development of the accounting profession in Australia by Abeysekera $(2006,68)$ highlighted a series of events that "strengthened the profession's authoritative position" in regards to dealings with the Australian Government. The analysis draws on the work of various authors focusing upon different stages of the development of the accounting profession. The events from 1946 to the late 1970's provided confirmation of the activities which promoted and then consolidated the power of the accounting profession (Birkett \& Walker 1962). In particular, the formation of the Australian Accounting Research Foundation (AARF) and the creation of the Australian Accounting Standards Committee (AASC) was undertaken to create a monopoly over the accounting standards. In the late 1970's the recognition of the standards by the Australian Government further increased the power of the profession (Heazlewood 2002). In the 1980's the Australian government did challenge the power of the accounting profession by requiring the membership of the newly formed Accounting Standards Research Board (ASRB) to be determined by the government rather than the accounting profession. This resulted in a compromise where the government controlled the ASRB and the accounting profession retained control over the AARF. Since 2000 the Australian Accounting Standards have been harmonized with the International Accounting Standards these events have arguably strengthened the position of the accounting profession over that of the government. This power of governments to intervene in the accounting standard setting is greatly reduced by the creation of the International Accounting Standards Board, which is perceived as providing a higher power of control and authority over the harmonization of accounting on a global basis. Thus the Australian accounting profession now has a higher authority from which to draw its privileged position.

\section{Conclusion}

In Australia the professional accounting bodies have achieved a monopolistic role over accounting through the credentialing process and legislative recognition of their authority to determine accounting standards. The implications of this process of closure points to a further strengthening of the "iron cage" of the profession, which draws on the German idealist view of social thought as exemplified by the works of Max Weber (Giddens 1975; Collins 1986). The accounting bodies have through their activities, such as accrediting university accounting degrees and conducting credentialing programs for membership status, achieved a form of closure over the accounting profession in Australia.

Through the lens of Weber's concept of a rational disciplinary society (O'Neill 1986) the discursive practices of the accounting profession in Australia, as identified in the paper, highlights the extent to which society (as represented by government agencies), accountants, and universities have subjected themselves to the 
professional bureaucracy. The bureaucracy, in this case the accounting profession, has exercise its authority to direct and maintain the conduct of social activities, in this case accounting standards, by providing a form of certainty through a rational and self-regulated framework. Weber (1978) pointed out that the individual was at risk of losing her/his individuality by becoming a part of the collective and to this end the accounting bodies have come to represent the profession and subsequently an individual is judged according to her/his membership of one of the accounting bodies. The recognition of the accounting bodies by the government, which is enshrined in key legislation, certainly has become part of the iron cage referred to by Weber (1978). Accepting the authority of the bureaucracy to dictate the rules of conduct within society traps an individual in an "iron cage" (Clegg 1992, 29). Thus, while the iron cage of the bureaucracy (Clegg 1992; Barker 1993) may be a social construct forged by rules its very existence provides form and substance which go beyond a mere social construct. The rules of the professional associations rationalize the conduct and behavior of members reinforcing the control which the bureaucracy exerts over its members and through the mantra of "professionalism" has inevitably extended into other areas of society, as evidenced by the accreditation process in the university sector and the recognition in government legislation and policy.

\section{References}

Abeysekera, I. (2006). Accounting meets Politics: Theoretical Interpretation of Key Events (1940-2003) of the Accounting Profession in Australia. Australian Accounting Review, 16(1), 66-74.

Australian Society of Certified Practicing Accountants \& The Institute of Chartered Accountants in Australia. (1991). Guidelines for Joint Administration of Accreditation of Tertiary Institutions by the Professional Accounting Bodies, Melbourne (Sydney), Author.

Bailey, A.R. (1994). Accounting Education: Gradual Transition or Paradigm Shift. Issues in Accounting Education, 9(1), 1-10.

Barker, J.R. (1993). Tightening the Iron Cage: Concertive Control in Self-Managing Teams. Administrative Science Quarterly, 38, 408-437.

Becher, T. (1994). The State and the University Curriculum in Britain. European Journal of Education, 29(3), 231-245.

Birkett, W.P. \& Walker, R.G. (1971). Response of the Australian Accounting Profession to Company Failure in the 1960's. Abacus, 2(2), 97-136.

Blewitt, A. (1990). Mathews Report Challenges Accounting Education. Charter, November, 58-59.

Bloom, R. \& Debessay, A. (1984). Educating Professional Accountants for the Twenty-First Century: A Point of View. Journal of Business Education, January, 159-162.

Boreham, P., Pemberton, A. \& Wilson, P. (1976). The Professions in Australia: A Critical Appraisal. St Lucia: University of Queensland.

Chambers, R.J. (1987). Accounting Education for the Twenty-first Century. ABACUS, 23(2), 97-106.

Chua, W. \& Poullaos, C. (1993). Rethinking the profession-state dynamic: the case of the Victorian charter attempt 1885-1906. Accounting, Organizations and Society, 18(7/8), 691-728.

Clegg, S.R. (1992). Modern Organizations: Organization Studies in the Postmodern World. London: SAGE Publications.

Collins, R. (1986). Weberian Sociological Theory. London: Cambridge University Press.

CPA, ICAA and NIA. (2010). Joint submission on Corporate Reporting Reforms. [Online] Available: http://www.treasury.gov.au/documents/1764/PDF/CPA_Australia_ICAA_and_NIA.pdf (19 January 2011).

Department of Employment, Education and Training. (1990). Accounting in Higher Education, Report of the Review of the Accounting Discipline in Higher Education, Volume 1, Main Report and Recommendations, July 1990. Canberra: Australian Government Publishing Service.

Feld, M.D. (1964). The Military Self-image in a Technological Environment, in M. Janowitz (ed.), The New Military. New York: Free Press.

Gardener, J.H. (1986). Task Force for Accounting Education. The Chartered Accountant in Australia, November, 6.

Gerstl, J. \& Jacobs, G. (1976). Professionals for the People: The Politics of Skill. New York: John Wiley and Sons.

Giddens, A. (1975). Capitalism and Modern Social Theory: An Analysis of the Writings of Marx, Durkheim and Max Weber. London: Cambridge University Press. 
Gynther, R.S. (1983). The Role of Tertiary Accounting Education in Today's Environment. Accounting and Finance, May, 1-19.

Hall, R. (1968). Professionalization and Bureaucratization. American Sociological Review, 33(1), 92-104.

Hawthorn, G. (1987). Enlightenment and Despair: A History of Social Theory (2nd Ed). London: Cambridge University Press.

Heazlewood, C.T. (2002). The Development of Accounting Regulation in Australia: A Contemporary Review, $9^{\text {th }}$ World Congress of Accounting Historians, Melbourne, 30 July - 2 August. [Online] Available: http:///www.deakin.edu.au/wcah/proceedings.html (18 January 2011).

Jackson, J.A. (1970). Professions and Professionalization. London: Cambridge University Press.

Johns, A. (1992). Accreditation: The Society Responds. Australian Accountant, June, 13.

Kamenka, E. (1989). Bureaucracy. Oxford: Basil Blackwell Ltd.

Kinney, W.R. Jr. (1990). Some Reflections on Professional Education: It Should Have Been More Positive. Issues in Accounting Education, 5(2), 295-301.

Larson, M.A. (1977). The Rise of Professionalism: A Sociological Analysis. Berkley: University of California Press.

Lee, T. (1990). The Closure of the Accounting Professions. New York: Garland.

Macdonald, K.M. (1985). Social Closure and occupational registration. Sociology, 19(4), 541-556.

Marsh, J.A. \& Henning, G.R. (1987). Some History of the Debate on Educational Policy of Accountants in Australia. ABACUS, 23(1), 55-69.

Min, H.K. (1987). The Scope and Objectives of Professional Accounting Education: Trends and Perspective. Journal of Education for Business, December, 104-109.

Murphy, R. (1984). The structure of closure: a critique and development of the theories Weber, Collins, and Parkin. British Journal of Sociology, 37(1), 21-41.

Murphy, R. (1985). Weberian closure theory: a contribution to the ongoing assessment. British Journal of Sociology, 37(1), 21-41.

O’Neill, J. (1986). The Disciplinary Society: From Weber to Foucault. The British Journal of Sociology, 37(1), 42-60.

Parkin, F. (1979). Marxism and Classical Theory: A bourgeois Critique. London: Tavistock.

Robson, K., Willmott, H., Cooper, D. \& Puxty, T. (1994). The Ideology of Professional Regulation and the Markets for Accounting Labour: Three Episodes in the Recent History of the U.K. Accountancy Profession. Accounting, Organizations and Society, 19(6), 527-553.

Scheiwe, D. (1992). Accreditation Anomalies. Australian Accountant, May, 36-39.

Schumpeter, J.A. (1951). Imperialism and Social Classes. Oxford: Alden Press.

Shanahan, J. (1990). Are Accountants Properly Educated? Australian Business, August 29, 77.

Smith, B.C. (1988). Bureaucracy and Political Power. Sussex: Wheatsheaf Books Ltd.

Snizek, W. (1972). Hall's Professionalism Scale: An Empirical reassessment. American Sociological Review, 37(1), 109-114.

Toren, N. (1976). Bureaucracy and Professionalism: A Reconsideration of Weber's Thesis. Academy of Management Review, 1(3), 36-46.

Walker, S. \& Shackleton, K. (1998). A ring fence for the profession: advancing the closure of British accountancy 1957-1970. Accounting, Auditing \& Accountability Journal, 11(1), 34-71.

Wallace W.A. (1990). One Educator's View of How to Respond to the Challenges Faced by Higher Education in Business. Issues in Accounting Education, 5(2), 302-306.

Weber, M. (1978). Economy and Society: An Outline of Interpretive Sociology (2 Vols), edited by G. Roth \& C. Wittich, Berkley: University of California.

West, B. (1996). The Professionalisation of Accounting: A Review of Recent Historical Research and its Implications. Accounting History, 1(1), 78-102.

Wilensky, H. (1964). The Professionalization of Everyone? The American Journal of Sociology, 70(2), 137-158. 